\title{
The use of Hand-Held XRF for investigating the composition and corrosion of Roman copper-alloyed artefacts
}

\author{
Ricardo Fernandes ${ }^{1,2^{*}}$, Bertil JH van Os ${ }^{3}$ and Hans DJ Huisman ${ }^{3,4}$
}

\begin{abstract}
The study of archaeological artefacts using deployed in situ analytical instruments presents some obvious advantages. Including, obtaining an immediate feedback that can be used to redefine in real-time fieldwork strategies. Ideally analytical field instruments should also have characteristics that limit damage to the studied artefact.

Here, we present a case study on the use of a Hand Held XRF (HH XRF) device employed to define the composition of copper-alloyed artefacts retrieved from the Roman military site of Fectio in the vicinity of Vechten (The Netherlands). The goals of the study were to establish artefact preservation status, to investigate artefact elemental composition, and to compare the composition of artefact corrosion layer and uncorroded core. The results showed that the objects were in an overall good preservation state. Decuprification and dezincification represented the probable main corrosion processes resulting in the formation of smooth corrosion layers or patinas. The major elemental composition of the artefacts' uncorroded cores showed a wide-range variability most likely associated with recycling practices of scrap metal during the $3^{\text {rd }}$ century CE.
\end{abstract}

Keywords: Roman, Copper-alloyed artefacts, Hand Held XRF, Vechten, Fectio, Metal corrosion

\section{Introduction}

Hand Held X-ray fluorescence devices (HH-XRF) and other portable XRF (pXRF) devices are regularly used in industry and are gradually being introduced also for archaeological/historical applications [1-5]. Within archaeometric research, previous studies have also employed pXRF devices in the measurement of the elemental composition of bulk and corrosion layers of copper-alloyed artefacts $[1,4]$. Given that this technique has the potential to provide high precision and fast results, allowing for non-destructive measurements to be made in situ, it becomes ideal for many archaeological applications.

In this study, a set of copper-alloyed archaeological artefacts from the Roman Limes military fort of Fectio, in the vicinity of Vechten (The Netherlands), were analysed using a HH-XRF device. The artefacts were recovered

\footnotetext{
* Correspondence: rfernandes@gshdl.uni-kiel.de

${ }^{1}$ Leibniz-Laboratory for Radiometric Dating and Isotope Research, Christian

Albrechts Universität, Max-Eyth-Str. 11-13, 24118 Kiel, Germany

${ }^{2}$ Graduate School "Human development in landscapes", Christian Albrechts

Universität, Kiel, Germany

Full list of author information is available at the end of the article
}

during a metal detector survey. The preservation status of the artefacts was established in two ways; macroscopically, by describing and classifying visible evidence for surface damage, and chemically by comparing elemental content $(\mathrm{Cu}, \mathrm{Pb}, \mathrm{Sn}, \mathrm{Zn})$ of each object's corroded surface and uncorroded core. These criteria provide information on two different corrosion effects. The first, surface damage represents a semi-qualitative criterion but that provides relevant information for archaeological research. The second, elemental variability is a quantitative criterion although not necessarily linked with loss of archaeological information.

The main goal of the present study was to provide an illustrative application of the use of a HH-XRF device in an archaeological context. The material selected for analysis contributes to the existing knowledge on the composition of Roman artefacts from a military Limes site occupied between the $1^{\text {st }}$ and $3^{\text {rd }}$ centuries CE. Finally, a simple assessment was made of the relationship between the preservation status of collected artefacts
() Chemistry Central

C 2013 Fernandes et al.; licensee Chemistry Central Ltd. This is an Open Access article distributed under the terms of the Creative Commons Attribution License (http://creativecommons.org/licenses/by/2.0), which permits unrestricted use,

distribution, and reproduction in any medium, provided the original work is properly cited. 
and observed variations in elemental composition due to the formation of corrosion layers.

\section{Materials and methods Artefacts}

Metallic artefacts, located using a metal detector, were collected from the top $30 \mathrm{~cm}$ of soil at the ancient site of Fectio; a Roman military settlement in the vicinity of modern day Vechten located approximately $5 \mathrm{~km}$ to the southeast of the city of Utrecht in The Netherlands [6-8]. The settlement was established during the Augustan period on the southern bank of a former Rhine bed, probably close to the spot where the river Vecht diverged from it $[7,9]$. The site was abandoned in the $3^{\text {rd }}$ century $C E$ when the river channel silted up [10].

The site had previously been the target of a baseline study to establish the preservation of copper-alloyed artefacts and its relationship with soil aggressiveness parameters [11]. The soil at the site is a thick and fairly impermeable clayey anthropogenic soil rich in lime and organic matter known in the Dutch soil classification as a "tuineerdgrond" (loosely translatable as garden plaggen soil). The topsoil consists of loam and sandy or silty clay. Due to intensive bioturbation and anthropogenic mixing, the profile is fairly homogeneous, with a black to black brown colour [11].

A total of 61 copper-alloyed artefacts were collected from the site (Additional file 1). The majority of the collected artefacts were assigned to the Roman period (44).
However, some more recent objects (e.g. brass buckshot shell casings) were also collected. Although some easily recognizable artefacts were found (Figure 1), most of collected objects were in a fragmentary state. The results here presented refer only to the archaeological artefacts assigned to the Roman period.

\section{Removal of corrosion layer}

To limit damage to each artefact the corrosion layer was removed only on a small area using a drill and a metal scalpel (Figure 2). The procedure in some cases was made difficult due to the thickness of the corroded layer and the small size of some of the artefacts.

\section{HH-XRF measurements}

For elemental measurements $(\mathrm{Cu}, \mathrm{Pb}, \mathrm{Zn}, \mathrm{Sn}$, and $\mathrm{Fe}) \mathrm{a}$ HH-XRF device was used. The HH-XRF device was a Thermo Scientific Niton XL3t with a GOLDD (Geometrically Optimised Large area Silicon Drift Detector) detector equipped with a silver anode operating at a maximum of $50 \mathrm{kV}$ and $40 \mu \mathrm{A}$. The device was factory calibrated and additional elemental standards were also measured.

Measurements were performed in a portable test stand with a lead liner and a helium purge was applied. Metal samples were placed over the exit of the detector and were measured in "mining mode" on their corrosion/patina layer (untreated surface), and on a treated spot. In this way, the compositional differences between the
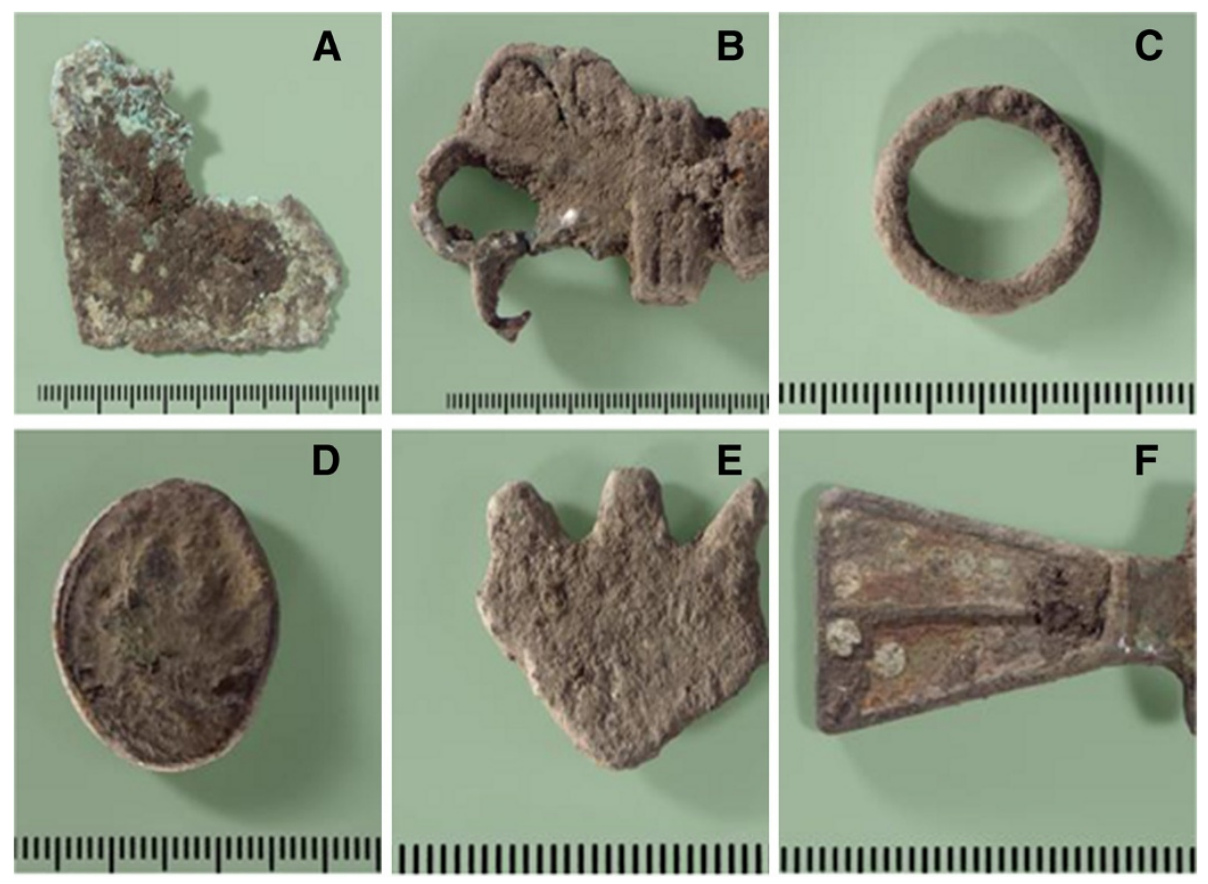

Figure 1 Examples of metallic artefacts located at Vechten. Sheet fragment (A), likely part of a key (B), ring (C), modern button (D), trident shaped artefact $\mathbf{( E )}$, unknown artefact (F). 


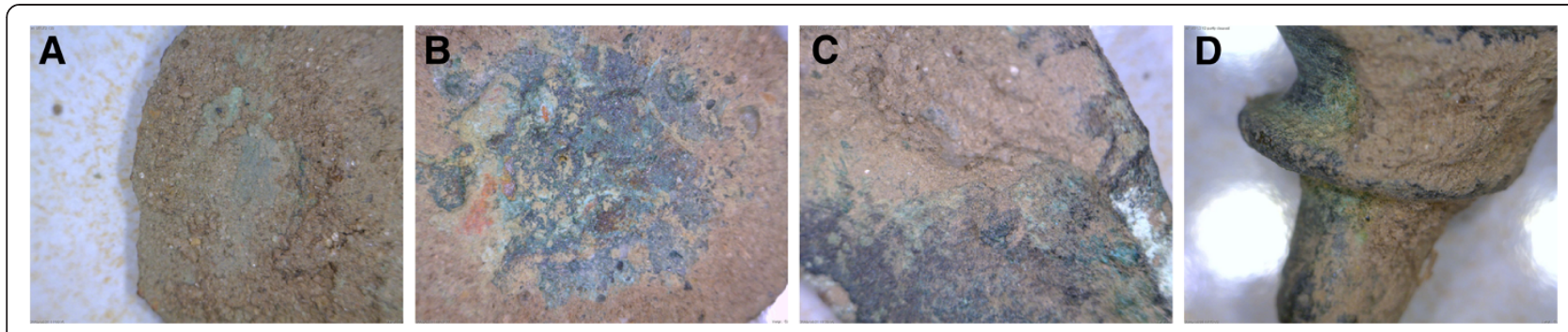

Figure 2 Examples of untreated and treated objects' surfaces. Sample 128 with untreated (A) and treated (B) surfaces. Sample 52 (C) with untreated upper part and treated lower part. Sample 12 (D) with untreated (right side) and treated (left side) surfaces.

corroded surface and the uncorroded core could be determined.

\section{Artefact preservation status}

The preservation status of each artefact was defined in accordance with the classification system described in Table 1 . This classification system considers the presence of pitting, overall preservation of artefact surface and shape, and the presence or not of corrosion scale.

\section{Results and discussion}

\section{Assessment of artefact preservation status}

Most of the objects, albeit fragmented, were relatively well preserved from corrosion attack (Table 2). The artefacts presented low amounts of pitting, with $82 \%$ having a score of 1 while the remaining $18 \%$ had a score of 2 . The surface of the majority of objects was also relatively well preserved with $48 \%$ having a score of $1,45 \%$ a score of 2 , and only $7 \%$ presenting a partially degraded surface (score 3). Defining preservation of shape was often difficult due to the fragmentary state of many of the objects.

Table 1 Parameters, and corresponding scores, used to define artefacts' preservation status

\begin{tabular}{lll}
\hline Parameter & Values & Individual scores \\
\hline Pitting & No pits & 1 \\
& Visible pitting & 2 \\
& Completely pitted & 3 \\
Preservation of surface & All details visible & 1 \\
& Details visible & 2 \\
& Surface partly degraded & 3 \\
& No original surface left & 4 \\
Preservation of shape & Object is complete & 1 \\
& Some damage is observed & 2 \\
& Object is partly deformed & 3 \\
& Object not recognizable & 4 \\
Corrosion scale & Not present & 0 \\
& Present & 1 \\
\hline
\end{tabular}

However, no heavy degradation of shape was observed, with $27 \%$ of the objects presenting small amounts of damage (score 2) and 73\% a good shape preservation (score 1). The presence of corrosion scales was observed in only $30 \%$ of the objects.

\section{Elemental composition}

Figure 3 shows box and whisker plots of the elemental composition $(\mathrm{Cu}, \mathrm{Pb}, \mathrm{Zn}, \mathrm{Sn}$, and $\mathrm{Fe})$ measured on the treated artefact surface of the copper-alloyed artefacts recovered from Vechten and assigned to the Roman period. The full list of measured artefacts is provided in Additional file 1.

The results show that all major elements are present in significant amounts and that these have wide ranges in concentration. This is especially evident for $\mathrm{Cu}$ and $\mathrm{Pb}$. The artefacts were classified according to their composition using Riederer's [12] classification to which was added the category of gunmetal (objects containing both zinc and tin). In accordance with this classification system the Vechten's artefacts are classified as tin bronzes $(18 \%)$, brasses $(6 \%)$, lead bronzes $(2 \%)$, lead tin brasses (26\%), and gunmetals (48\%) (Figure 4).

The mechanical properties of bronze make it an ideal choice for the fabrication of different objects including weapons. The use of tin bronze became almost universal in Europe by the end of the second millennium BCE [13]. The Romans employed great quantities of both low tin and high tin bronzes, especially prior to the large scale introduction of brass during the late $1^{\text {st }}$ century BCE [14].

The production of metallic zinc is problematic since zinc evaporates at $950^{\circ} \mathrm{C}$ while it requires a temperature of around $1000^{\circ} \mathrm{C}$ to be reduced from zinc ores. Thus in a smelting process metallic zinc is evaporated and quickly converted into an oxide. During the $1^{\text {st }}$ century $\mathrm{BCE}$ brass was produced through the direct mix of copper and zinc ores in a closed crucible at $1000^{\circ} \mathrm{C}$, this process is referred as co-smelting or cementation [15]. The Romans were the first to produce brass on a large scale, with brass representing one third of the copper 
Table 2 Distribution of preservation scores for Roman objects found at Vechten

\begin{tabular}{llllll}
\hline Criterion & Score 0 (\%) & Score 1 (\%) & Score 2 (\%) & Score 3 (\%) & Score 4 (\%) \\
\hline Pitting & - & 82 & 18 & 0 & - \\
Preservation of surface & - & 48 & 45 & 7 & 0 \\
Preservation of shape & - & 73 & 27 & - & 0 \\
Corrosion scale & 70 & 30 & - & - \\
\hline
\end{tabular}

alloys used during the Roman Imperial period. Zinc content for early Roman brasses is typically in the $18-24 \%$ range [16].

During the Roman period lead was cheaper and more easily obtainable than zinc or other metals, and high lead contents are often observed in casted objects. When up to $2 \%$ lead is added to an alloy there is a significant increase in the mobility of the molten metal [15]. Further increases in lead content (3-4\%) does not increase significantly the fluidity of the alloy but there is a lowering in melting point. This makes leaded bronzes easier to cast, but also easier to drill, file or grind [15]. Metallic lead oxidizes very quickly and forms a passive oxide layer within seconds and is therefore very corrosion resistant. Furthermore, lead is very malleable and was widely used by the Romans in the making of a large variety of objects, including, the making of funerary urns, inscribed tablets, pipes, coins, etc [17-19].

Over $60 \%$ of the measured artefacts had iron contents above 5\%. These high iron levels may, in part, originate from impurities in the copper ore. High concentrations of iron in Roman alloyed artefacts have been previously reported [20]. For instance, dupondi and sestertii, early Roman brass coinage, had higher iron content than contemporary bronzes [15]. However, compared with the results here presented (Figure 3) the study by Dungworth showed, for Roman artefacts, a lower maximum iron content of $2 \%$ [21]. Therefore, the observed high levels of iron probably result from post depositional processes with the applied surface treatment not completely removing iron containing clay minerals such as illite. Additionally, given the small sizes of some of the artefacts and the need to limit the removal of the corrosion layer it is possible that portions of untreated surface were also targeted by the primary X-ray beam.

Compositional differences are expected for artefacts depending on their functional characteristics. However, observed wide variations in elemental concentrations are most likely attributable to common and time extended recycling practices of scrap metal. Similar compositional ranges have been previously reported on Roman British objects from the $3^{\text {rd }}$ and $4^{\text {th }}$ centuries CE [21]. This contrasted with previous centuries where lower amounts of leaded bronze or leaded brass were observed and unleaded brasses and bronzes were more prevalent. Increased alloying with lead during the later stages of the Roman Empire has also been reported for objects having a unique function (e.g. statuary) [22]. Given that the majority of retrieved objects are most likely reflecting the later phases of site occupation it can be hypothesized that rather than the specific physical properties of leaded alloys determining the choice of their use, the large

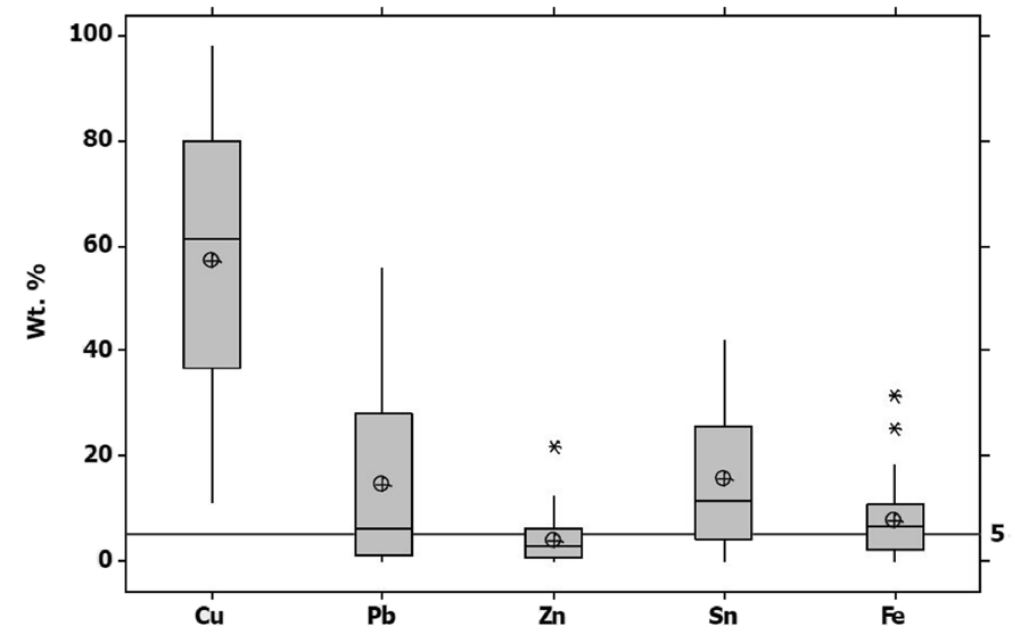

Figure $3 \mathrm{Box}$ and whisker plot showing the distribution of $\mathrm{Cu}, \mathrm{Pb}, \mathrm{Zn}, \mathrm{Sn}$, and Fe weight content of the Roman objects found at Vechten. Asterisks indentify compositional outliers, while circles with cross within identify mean values. The measurements refer to treated artefacts, that is, surface measurements for which the corrosion layer was removed. 


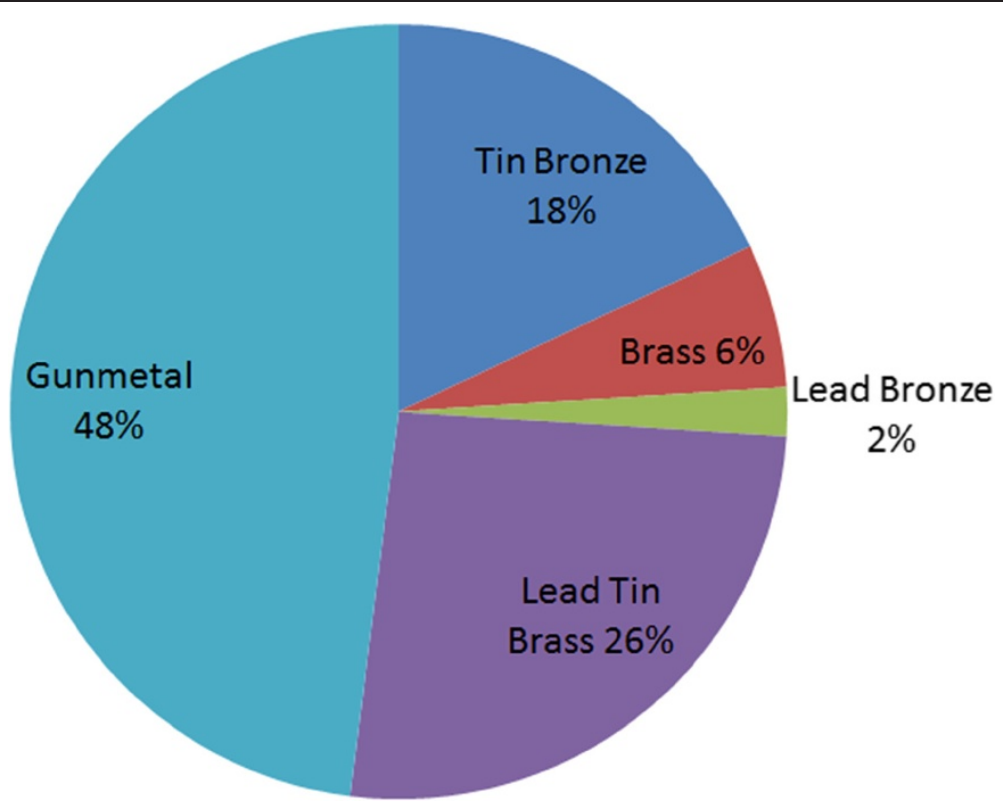

Figure 4 Compositional distribution of Roman artefacts according to Riederer's (1984) classification with the added category of gunmetal.

compositional variation resulted from difficulties in accessing alternative metals during the $3^{\text {rd }}$ century CE. This hypothesis is framed within the unstable political and economic situation of the Roman Empire during the $3^{\text {rd }}$ century CE.

\section{Differences in composition of treated and untreated artefact surfaces}

The composition of untreated metal surfaces, for all collected objects and measured elements, is reported in Additional file 1. Table 3 shows, for artefacts assigned to the Roman period, the relative enrichment or depletion in the concentration of major elements $(\mathrm{Cu}, \mathrm{Pb}, \mathrm{Zn}$, and $\mathrm{Sn})$ determined by comparing the elemental contents of the corroded surface and the uncorroded core.

In $82 \%$ of the objects the results showed depletion in copper content when comparing the corrosion layer with bulk alloy composition (Table 3). Standard tin bronzes present a microstructure consisting of a delta phase (tin rich) interspersed by dendritic arms of a copper rich alpha

Table 3 Percentages of elemental enrichment or depletion for metal objects retrieved at Vechten established by comparing the composition of treated and untreated artefact surface

\begin{tabular}{lll}
\hline Element & Enrichment (\%) & Depletion (\%) \\
\hline $\mathrm{Cu}$ & 18 & 82 \\
$\mathrm{~Pb}$ & 57 & 43 \\
$\mathrm{Zn}$ & 36 & 64 \\
$\mathrm{Sn}$ & 63 & 37 \\
\hline
\end{tabular}

phase [23]. In an oxygenated environment the delta phase is more resistant to corrosion than the alpha phase resulting in the selective dissolution of copper (decuprification). Tin remains in the alloy surface as oxide and the values for tin in Table 3 show that tin enrichment occurs in $63 \%$ of all samples. In a decuprification process even surfaces (Type I surfaces) or patinas consisting of copper oxides and copper carbonates are usually formed [24]. Thus, corrosion mechanisms in which decuprification predominates are consistent with surface preservation results that indicated low amounts of pitting and limited formation of corrosion scales (Figure 2, Table 2).

Brass artefacts are well known for being less hard and less corrosion resistant than bronze artefacts [25]. Brass alloys are subject to dezincification in which zinc is selectively leached. Zinc is either deposited as an insoluble compound or carried away as a soluble salt, while copper is re-deposited at the alloy surface in a porous form [26]. Objects showing zinc depletion represent the majority $(64 \%)$ although there is still a significant percentage of objects showing zinc enrichment (36\%). Corrosion studies on Roman coins have previously shown that the presence of alloy tin limits dezincification [27]. This may also explain the significant percentage of Vechten objects showing zinc enrichment.

Alloy lead is immiscible in the copper matrix forming discrete globules. Buried lead objects generally do not corrode severely [28]. However, high concentrations of lead might lead to the aggregation of dispersed globules causing a weakening of the mechanical properties of the alloy [15]. The Vechten objects exhibited similar 
percentages of relative lead depletion (43\%) and enrichment (57\%).

\section{Conclusions}

A Hand-Held XRF (HH XRF) device is an analytical tool well suited for investigating major elemental composition of metallic archaeological artefacts. It can be deployed for measurements in situ ensuring limited or no damage to measured artefacts. A HH XRF device was used to provide an insight into the composition of copper-alloyed artefacts from the Roman site of Fectio in the vicinity of Vechten (The Netherlands).

Retrieved copper-alloyed artefacts were in an overall good preservation status owing to the local characteristics of the clayey carbonate containing soil that limited access to atmospheric oxygen and assured a neutral to slightly alkaline $\mathrm{pH}$. The objects, albeit fragmented, showed a good surface preservation through the formation of smooth corrosion layers. The formation of such smooth layers is consistent with comparison of the elemental composition of the corrosion layer and uncorroded core that indicate that decuprification and dezincification were the main corrosion processes.

The artefacts presented wide compositional ranges of major elements $(\mathrm{Cu}, \mathrm{Sn}, \mathrm{Zn}$, and $\mathrm{Pb})$. These are probably associated with recycling practices of scrap metal, and a time-related increase in lead content. Compositional results offer a scenario similar with other locations within the Roman Empire during the $3^{\text {rd }}$ century (time of abandonment of the site), a period well-known for its political and financial instability.

\section{Additional file}

Additional file 1: Chemical composition and preservation status of copper-alloyed artefacts collected at Vechten.

\section{Competing interests}

The authors declare that they have no competing interests.

\section{Authors' contributions}

RF wrote the manuscript revised by $\mathrm{BJHO}$ and $\mathrm{HDJH}$. RF and $\mathrm{BJHO}$ collected objects during fieldwork. RF, BJHO, and $\mathrm{HDJH}$ performed analytical measurements. All authors read and approved the final manuscript.

\section{Acknowledgments}

This study was carried out within the scope of an internship made possible by the Cultural Heritage Agency of the Netherlands. The authors would like to thank Prof. Henk Kars (Vrije Universiteit Amsterdam) for introducing Ricardo Fernandes to the Dutch archaeometric community and for supervising the internship. The authors would like also to thank Jo Kempkens and Ton Lupak from Restaura (Haelen, The Netherlands) for assisting in the cleaning and restoration of the artefacts, and for providing access to a micro camera. Finally, two anonymous reviewers are thanked for their helpful comments.

\section{Author details}

${ }^{1}$ Leibniz-Laboratory for Radiometric Dating and Isotope Research, Christian Albrechts Universität, Max-Eyth-Str. 11-13, 24118 Kiel, Germany. ${ }^{2}$ Graduate
School "Human development in landscapes", Christian Albrechts Universität, Kiel, Germany. ${ }^{3}$ Cultural Heritage Agency, P.O. Box 1600, 3800, BP Amersfoort, The Netherlands. ${ }^{4}$ Faculty of Archaeology, Leiden University, Leiden, The Netherlands.

Received: 31 March 2013 Accepted: 9 September 2013 Published: 16 September 2013

\section{References}

1. Cesareo R, Stefano R, Marabelli M, Castellano A, Buccolieri G, Donativi M: Portable systems for energy-dispersive $\mathrm{X}$-ray fluorescence analysis of works of art. In Portable X-ray fluorescence spectrometry. Edited by Potts PJ, West M. Cambridge, UK: RSC Publishing; 2008:206-243.

2. Karydas AG, Brecoulaki X, Pantazis T, Aloupi E, Argyropoulos V, Kotzamani D: Importance of in situ EDXRF measurements in the preservation and conservation of material culture. In X-rays for archaeology. Edited by Uda M, Demortier G, Nakai I. Dordrecht, The Netherlands: Springer; 2005:27-54.

3. Phillips SC, Speakman RJ: Initial source evaluation of archaeological obsidian from the Kuril Islands of the Russian Far East using portable XRF. J Archaeol Sci 2009, 36:1256-1263.

4. Vittiglio G, Janssens K, Vekemans B, Adams F, Oost A: A compact smallbeam XRF instrument for in situ analysis of objects of historical and/or artistic value. Spectrochim Acta Part B 1999, 54:1697-1710.

5. Williams-Thorpe O: The application of portable X-ray fluorescence analysis to archaeological lithic provenancing. In Portable X-ray fluorescence spectrometry. Edited by Potts PJ, West M. Cambridge, UK: RSC Publishing; 2008:174-203

6. Kalee CA: Roman helmets and other militaria from Vechten. In Fifth roman military equipment conference. Edited by van Driel-Murray C. Oxford, UK: British Archaeological Reports; 1989:193-226.

7. Polak M, Wynia SL: The Roman forts at Vechten a survey of the excavations 1829-1989. Leiden, The Netherlands: Rijksmuseum van Oudheden; 1991.

8. Brulet R, Leva C, Mertens J, Plumier J, Thollard P: Forts Romains de la route Bavay-Tongres. In Roman Frontier studies 1995: proceedings of the XVIth international congress of roman frontier studies. Edited by Groenman-Van W. Oxford, UK: Oxbow Books; 1997:1-24.

9. Bosman A, de Weerd M: Velsen: the 1997 excavations in the early Roman base and a reappraisal of the post-Kalkriese Velsen/Vechten dating evidence. In Archaeology in confrontation. Aspects of roman military presence in the northwest (studies in honour of Prof. Em. Hugo thoen). Edited by Vermeulen F, Sas K, Dhaeze W. Academia Press; 2004:31-62.

10. Derks T, Vos W: Wooden combs from the Roman fort at Vechten: the bodily appearance of soldiers. J Archaeol Low Countries 2010, 2. http://dpc. uba.uva.nl/jalc/02/nr02/a03.

11. Wagner D, Kropp M, Abelskamp-Boos KA, Dakoronia NE, Ferguson C, Fischer WR: Soil archive classification of European excavation sites in terms of impacts of conservability of archaeological heritage. Iserlohn: European Commission; 1997.

12. Riederer J: Metallanalysen römischer Bronzen. In Toreutik und figürliche Bronzen römischer Zeit. Akten der 6. Tagung über antike Bronzen. Antikenmuseum: Preussischer Kulturbesitz Berlin; 1984:220-225.

13. Craddock PT: Early metal mining and production. Washington D.C., USA: Smithsonian University Press; 1995.

14. Theelen M: Chemical analysis of Roman bronzes from Naaldwijk. Amsterdam, The Netherlands: IGBA Rapport 2007-04; 2007.

15. Craddock PT: Three thousand years of copper alloys: from the Bronze Age to the industrial revolution. In Application of science in the examination of works of Art. Edited by England PA, van Zelst L. Boston: Museum of Fine Arts; 1985:59-67.

16. Craddock PT: The copper alloys of the Medieval Islamic world inheritors of the classical tradition. World Archaeol 1979, 11:68-79.

17. Toller H: Roman lead coffins and ossuaria in Britain. Oxford, UK: British Archaeological Reports vol. 38; 1977.

18. Tomlin RS: Tabellae Sulis: Roman inscribed tablets of tin and lead from the sacred spring at Bath. Oxford, UK: Oxford University Committee for Archaeology; 1988

19. Rapp GR: Archaeomineralogy. Berlin, Germany: Springer; 2009.

20. Dungworth D: Iron Age and roman copper alloys from northern Britain. Internet Archaeo/ 1997, 2. http://intarch.ac.uk/journal/issue2/ dungworth_index.html.

21. Dungworth D: Roman copper alloys: analysis of artefacts from northern Britain. J Archaeol Sci 1997, 24:901-910. 
22. Robbiola L, Portier R: A global approach to the authentication of ancient bronzes based on the characterization of the alloy-patina-environment system. J Cultur Herit 2006, 7:1-12.

23. Srinivasan S: The use of tin and bronze in prehistoric southern Indian metallurgy. J Met Mater Miner 1998, 50:44-48.

24. Robbiola L, Blengino J, Fiaud C: Morphology and mechanisms of formation of natural patinas on archaeological $\mathrm{Cu}-\mathrm{Sn}$ alloys. Corros $\mathrm{SCi}$ 1998, 20:2083-2111.

25. Scott DA: Copper and bronze in art, corrosion, colorants, and conservation. Los Angeles, USA: Getty Publications; 2002.

26. Schweitzer PA: Metallic corrosion: atmospheric and media corrosion of metals. Florida, USA: CRC Press; 2007.

27. Campanella L, Alessandri OC, Ferretti M, Plattner SH: The effect of tin on dezincification of archaeological copper alloys. Corros Sci 2009, 51:2183-2191.

28. Schotte B, Adriaens A, Dhooghe F, Depla D, Dierick M, Dowsett M, Lehmann E, Vontobel P: Chemical and morphological changes of historical lead objects as a result of the use of electrolytic reduction as a stabilization treatment. Anal Chem 2006, 76:8319-8323.

doi:10.1186/2050-7445-1-30

Cite this article as: Fernandes et al:: The use of Hand-Held XRF for investigating the composition and corrosion of Roman copper-alloyed artefacts. Heritage Science 2013 1:30.

\section{Publish with ChemistryCentral and every scientist can read your work free of charge \\ "Open access provides opportunities to our colleagues in other parts of the globe, by allowing anyone to view the content free of charge." \\ W. Jeffery Hurst, The Hershey Company. \\ - available free of charge to the entire scientific community \\ - peer reviewed and published immediately upon acceptance \\ - cited in PubMed and archived on PubMed Central \\ - yours - you keep the copyright \\ Submit your manuscript here: \\ http://www.chemistrycentral.com/manuscript/<smiles>c1ccccc1</smiles> \\ Chemistry Central}

